\title{
Pengaruh Efektifitas Diri Dan Spesifik Internet Terhadap Tingkat Ansietas Pengguna Internet
}

\author{
Ibnu Harris $^{1 *}$, Ahmad Fitriansyah ${ }^{2}$ \\ Universitas Universal, Batam \\ *Korespondensi: ibnu@uvers.ac.id
}

\begin{abstract}
Abstrak
Ansietas atau rasa tidak nyaman seorang pengguna internet bisa dirasakan dalam berbagai macam bentuk. Orang yang kurang percaya diri akan kemampuannya dalam menggunakan internet, tidak puas akan keahlian internet ataupun perasaan tidak nyaman dalam menggunakan internet dapat dikatakan memiliki efektivitas diri yang lemah. Penelitian ini berjenis kuantitatif dengan pendekatan kausal komparatif, yaitu membahas masalah berupa hubungan sebab akibat antara variabel independen (efektivitas diri dan spesifik internet) dengan variabel dependen (ansisetas pengguna internet). Populasi dalam penelitian ini adalah seluruh dosen, tenaga kependidikan, dan mahasiswa yang aktif pada tahun akademik 2016/2017 di Universitas Universal (UVERS). Adapun sampel yang diambil dan layak digunakan sebagai sumber data primer sebanyak 222 orang, dengan teknik pengambilan data purposive sampling. Alat analisa menggunakan Regresi Linear Berganda, Uji-T, dan Uji-F. Hasil penelitian ini menunjukkan Efektivitas diri tidak memiliki pengaruh yang signifikan dengan ansietas pengguna internet. Hal ini juga menunjukkan semakin tinggi tingkat efektivitas diri seorang pemakai internet, maka belum tentu menyebabkan perubahan tingkat ansietas pengguna internet. Akan tetapi factor spesifik internet, berpengaruh pada ansietas pengguna internet.
\end{abstract}

Kata Kunci: Ansietas pengguna internet, Efektivitas diri, Faktor spesifik internet

\begin{abstract}
Anxiety or discomfort of an internet user can be felt in various forms. People who lack confidence in their ability to use the internet, are not satisfied with internet skills or feel uncomfortable in using the internet can be said to have weak self-effectiveness. This research is a quantitative type with a comparative causal approach, namely discussing the problem in the form of a causal relationship between independent variables (selfeffectiveness and internet-specific) and the dependent variable (internet user hacking). The population in this study were all lecturers, education staff, and students active in the 2016/2017 academic year at Universal University (UVERS). The samples taken and are suitable to be used as primary data sources as many as 222 people, with purposive sampling data collection techniques. Analyzer uses Multiple Linear Regression, T-Test, and F-Test. The results of this study indicate that self-effectiveness does not have a significant effect on the anxiety of internet users. This also shows the higher level of effectiveness of an internet user, so it does not necessarily cause changes in the level of anxiety of internet users. However, specific internet factors have an effect on the anxiety of internet users. Keywords: Internet users anxiety, self-effectiveness, internet-specific factors.
\end{abstract}

\section{A. PENDAHULUAN}

Technophobia adalah golongan dari ansietas (Bowers dan Bowers, 1996) yang didefinisikan sebagai sebuah reaksi yang disebabkan oleh rasa takut karena perasaan malu dan ketegangan sosial. Menurut Glass dan Knight (1998), perasaan umum yang berhubungan dengan ansietas adalah kejengkelan, frustasi, kegagalan untuk memahami, permusuhan dan penyerangan. Menurut Dinev (2002), pemakaian dan pengaksesan internet mempunyai implikasi yang penting di bidang ekonomi, pendidikan dan sosial. Hal ini yang mendorong penulis melakukan penelitian replikasi pada instansi pendidikan yang didirikan dengan tujuan selain melaksanakan misi mendidik tetapi 
juga harus untung. Pada penelitian ini tidak menggunakan seluruh variabel yang digunakan pada penelitian Dinev (2002).

Pemakaian dan pengaksesan internet membawa keuntungan yang banyak kepada pemakai internet seperti produktivitas pekerjaan, pendidikan, pengaksesan informasi, memperbaharui teknologi, persatuan sosial dan profesional, serta keuntungan bagi pembeli. Menurut O'Neil (1995), pengaksesan ke teknologi memperbolehkan orang yang terpisah oleh waktu dan tempat untuk mengembangkan suatu dunia buatan, di mana pengguna dapat bekerja sama untuk memperkembangkan pengalaman virtual yang umum.

Menurut Dinev (2002) ansietas biasanya muncul ketika sesuatu yang baru dipelajari. Ansietas pengguna internet bisa dirasakan dalam berbagai macam bentuk. Ansietas ini bisa muncul ketika pemakai internet sedang melakukan pembelian barang secara online, berbagi informasi di discussion board, men-download perangkat lunak, dan lain-lain. Ada juga beberapa pemakai internet yang cenderung timbul rasa curiga yang bahkan kadang-kadang tidak beralasan tentang kerusakan potensial yang bisa terjadi ketika mereka berinternet, misalnya kerusakan sistem komputer karena virus, kesalahan dalam melakukan tugas, dan lain-lain.

Eastin dan LaRose (2000) melakukan penelitian terhadap 171 mahasiswa universitas di Midwestern menunjukkan bahwa efektivitas diri dalam berkomputer memiliki hubungan yang signifikan dengan pengalaman berinternet sebelumnya. Efektivitas diri dalam berinternet berkorelasi secara positif dengan pemakaian internet yang dikarenakan oleh pengalaman berinternet sebelumnya. Pengalaman berinternet sebelumnya merupakan penyebab yang signifikan dari efektivitas diri dalam berinternet. Menurut Eastin dan LaRose (2000), pengalaman yang lebih dari 2 tahun dapat mencapai efektivitas diri yang cukup.

Berdasarkan paparan di atas, rumusan masalah yang diangkat dalam penelitian ini adalah: Apakah efektifitas diri serta spesifikasi internet berpengaruh terhadap ansietas pengguna internet di Universitas Unversal Batam? Hal ini menggugah minat penulis untuk melakukan penelitian lebih lanjut karena berdasarkan pengamatan singkat peneliti, ditemukan bahwa terdapat sivitas akademik yang selalu menyatakan keluhan apabila diberikan tugas yang mengharuskannya menggunakan internet. Padahal, koneksi dan alat untuk menggunakan internet telah disediakan dengan sangat memadai.

\section{B. KAJIAN PUSTAKA}

\section{Ansietas Komputer}

Penerimaan dan adopsi terhadap teknologi baru untuk menjadi penggunaan yang nyata adalah hal yang sangat kompleks, sulit dan menjadi fenomena yang penting (Harris, 2017). Menurut Ayersman dan Reed (1995), ansietas komputer adalah sebuah kondisi sementara yang dapat berkurang melalui sebuah lingkungan belajar yang nyaman. Presno (1998) menemukan 1 (satu) kesamaan dari 4 (empat) penyebab ansietas tersebut, yaitu rendahnya efektivitas diri. Efektivitas diri yang rendah menyebabkan timbulnya ansietas dalam berinternet. Keempat area ansietas internet tersebut, yaitu:

1. Terminology anxiety yaitu ketika para siswa dibanjiri oleh istilah internet yang baru, terutama jika instruktur menganggap bahwa siswa mengerti akan istilah-istilah tersebut. 
2. Net search anxiety yaitu perasaan frustasi akan secara cepat membayangi para siswa ketika gagal tiba di lokasi yang diinginkan di internet.

3. Internet time delay anxiety yaitu para siswa akan menjadi cepat marah dan frustasi ketika mendapatkan sinyal sibuk dan penundaan waktu ketika menggunakan internet, terutama ketika bekerja di bawah limit waktu.

4. General fear of internet failure yaitu kepedulian para siswa terhadap ketidaksanggupan untuk menggunakan internet.

Waxman, H. C., dan Padron, Y.N. (1995), lebih menitikberatkan pada pengalaman berkomputer yang terbatas berhubungan dengan tingginya tingkat ansietas komputer dan rendahnya rasa percaya diri dalam menggunakan komputer. Faktor penyebab ansietas siswa terhadap komputer ada bermacam-macam. Menurut Al-Jabri dan Al-Khaldi (1996), karakteristik-karakteristik seperti umur, kepemilikan komputer, kemudahan pengaksesan komputer, pengalaman berkomputer adalah faktor ansietas seorang siswa terhadap komputer. Begitu juga Bashir, I \& Madhavaiah, C. (2015) menyatakan individu yang menilai teknologi baru seperti Internet Perbankan adalah dapat dipercaya, umumnya pada posisi lebih baik untuk merasa yakin menggunakannya dan diharapkan mereka untuk menggunakannya.

Hasil dari penelitian Necessary dan Parish (1996) menunjukkan bahwa peningkatan pengalaman berkomputer dan pemakaian komputer yang seimbang setiap minggu berhubungan dengan pengurangan tingkat ansietas yang berhubungan dengan komputer. Hopson (2001) juga menyatakan dilakukan terhadap para siswa, ditemukan bahwa tingginya tingkat ansietas komputer berkorelasi dengan rendahnya nilai untuk pelajaran komputer. Ketika siswa hanya menggunakan komputer beberapa kali dalam pelajaran komputer maka kecemasan komputer menjadi meningkat.

\section{Efektivitas Diri}

Bandura (1997) menyatakan bahwa efektivitas diri adalah keyakinan pribadi dari sebuah persepsi individual akan kemampuan untuk melakukan sebuah tindakan yang diperlukan untuk mencapai sebuah hasil. Menurut Compeau dan Higgins (1995), efektivitas diri menunjukkan kepada penilaian akan kemampuan seseorang untuk menggunakan komputer. Orang yang kurang percaya diri akan kemampuannya dalam menggunakan internet, tidak puas akan keahlian internet ataupun orang yang merasa tidak nyaman dalam menggunakan internet dapat dikatakan memiliki efektivitas diri yang lemah. Penelitian Feldman (2000) yang dilakukan di Israel dengan sampel sebanyak 309 orang menunjukkan bahwa ada korelasi yang signifikan antara ansietas komputer dengan efektivitas diri. Hasil penelitian juga menunjukkan adanya perbedaan signifikansi antara kelompok siswa yang pernah menggunakan berbagai perangkat lunak seperti pengolah kata dibandingkan dengan kelompok yang tidak pernah menggunakannya.

Berdasarkan penelitian pilot yang dilakukan oleh Dinev dan Koufteros (2003) menunjukkan bahwa tingkat penggunaan internet secara positif berhubungan dengan efektivitas diri dalam berinternet dari pemakai internet juga terdapat korelasi yang positif antara pelatihan internet dengan efektivitas diri dalam berinternet. Sampel dari penelitian tersebut terdiri 346 orang pemakai internet di daerah timur bagian selatan Amerika Serikat.

Konerding (2000) melakukan penelitian di Universitas Humboldt, Jerman menunjukkan dari sampel 249 siswa terdapat korelasi antara ansietas komputer dengan efektivitas diri dalam berkomputer dengan tingkat signifikansi $p<0,001$. Hasil penelitian tersebut menunjukkan pengalaman berkomputer atau kinerja komputer 
berkorelasi secara positif dengan efektivitas diri dalam berkomputer, dan terjadi peningkatan efektivitas diri dalam berkomputer bagi siswa yang mengikuti kelas komputer. Konerding (2000) juga menemukan bahwa terjadi peningkatan efektivitas diri dalam berkomputer bagi siswa yang berinteraksi secara langsung dengan komputer dengan dibantu oleh guru. Boyle, R. dan Ruppel, C. (2003) menemukan adanya korelasi antara efektivitas diri dalam berkomputer dengan persepsi penggunaan sebesar $-0,032$ yang signifikan pada $\mathrm{p}<0,02$. Penelitian tersebut dilakukan terhadap 110 mahasiswa di sebuah universitas di Southeastern Amerika Serikat, yang terdiri dari mahasiswa jurusan Pemasaran, Sistem Informasi dan jurusan non bisnis lainnya.

Hasil penelitian Lopez dan Manson (1997) terhadap 100 orang manajer di Alhambra, California menunjukkan bahwa efektivitas diri dalam berkomputer akan secara positif berhubungan dengan penggunaan sistem informasi. Menurut Lopez dan Manson (1997), kepercayaan individu tentang kemampuan mereka dalam menggunakan komputer juga dipastikan sebagai konstruk yang relevan dalam keputusan penggunaan sistem informasi. Penelitian yang dilakukan di sebuah college di Amerika Serikat (Johnson et al., 2001) pada tahun 1999 dan 2000 terhadap 153 orang siswa menunjukkan hasil ujian pengetahuan komputer dan jumlah mata kuliah komputer yang diambil secara signifikan $(\mathrm{p}<0,05)$ berkorelasi positif dengan efektivitas diri dalam berkomputer. Penelitian tersebut bertujuan untuk menentukan pengalaman berkomputer, efektivitas diri dalam berkomputer dan pengetahuan komputer di 2 tahun ajaran yang berbeda.

Decker (1998) menyatakan bahwa jenis pekerjaan, pengalaman pelatihan komputer sebelumnya, pemakaian dalam komputer, frekwensi pemakaian komputer dan tanggung jawab pelatihan ditemukan memiliki hubungan terhadap efektivitas diri dalam berkomputer. Penelitian tersebut dilakukan terhadap 357 pekerja di universitas yang telah mendapatkan pelatihan komputer selama 2,5 tahun. Hasil penelitian Dinev (2002) terhadap 304 mahasiswa di Universitas Southeastern menunjukkan bahwa efektivitas diri mempengaruhi ansietas pengguna internet.

\section{Faktor Spesifik Internet}

Dinev (2002) menyatakan bahwa ansietas pengguna internet berhubungan dengan tingkat kenyamanan dari komunikasi secara online, seperti mengisi formulir secara online, upload atau download data dan membeli barang melalui situs web. Dengan mengetahui pentingnya faktor spesifik internet ini diperlukan untuk mengenal lebih jelas konstruk ansietas internet. Dari penelitian Dinev (2002) dapat diketahui bahwa faktor spesifik internet memengaruhi ansietas pengguna internet. Para responden peduli akan adanya virus, masalah privacy, dan pelanggaran keamanan yang menunjukkan bahwa mereka memiliki tingkat ansietas yang tinggi ketika menggunakan internet.

\section{Model penelitian dan Perumusan Hipotesis}

Konstruk penelitian yang akan diuji terdiri dari efektivitas diri, faktor spesifik internet, yang berperan sebagai variabel independen dan ansietas pengguna internet, yang berperan sebagai variabel dependen. Berdasarkan kerangka pemikiran tersebut, maka model penelitian ini adalah: 


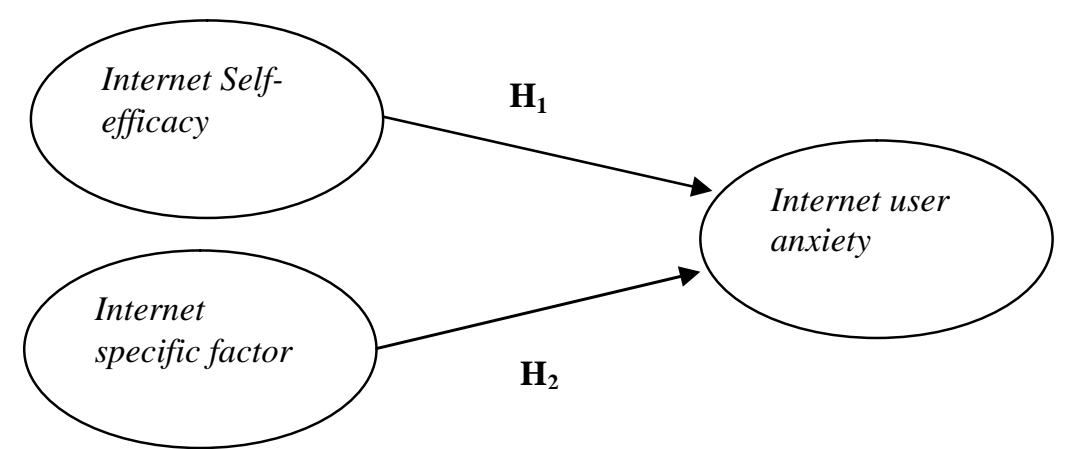

Sumber : Dinev (2002)

\section{Gambar 1: Model Penelitian}

Berdasarkan model penelitian di atas, maka perumusan hipotesis untuk penelitian ini adalah sebagai berikut:

$\mathrm{H}_{0}$ : Tidak terdapat hubungan dan pengaruh yang signifikan antara efektivitas diri pengguna internet dan faktor spesifik internet terhadap tingkat ansietas pengguna internet.

Sedangkan Hipotesis alternatif yang diharapkan dapat dibuktikan bahwa:

$\mathrm{H}_{1}$ : Terdapat pengaruh yang signifikan dari efektivitas diri terhadap tingkat ansietas pengguna internet.

$\mathrm{H}_{2}$ : Terdapat pengaruh faktor spesifik internet yang siginifikan terhadap tingkat ansietas pengguna internet.

\section{METODE PENELITIAN}

Penelitian ini berjenis kuantitatif dengan pendekatan kausal komparatif, yaitu tipe penelitian dengan karakteristik masalah berupa hubungan sebab akibat antara 2 (dua) variabel atau lebih yang meliputi variabel independen dan variabel dependen, dengan tujuan untuk mengetahui seberapa besar pengaruhdengan menggunakan pendekatan. Adapun variabel dependen dalam penelitian ini adalah ansietas pengguna internet. Sedangkan variabel independen terdiri dari efektivitas diri dan faktor spesifik internet. Penelitian ini menggunakan instrumen yang telah dikembangkan dan diuji dalam penelitian Dinev (2002).

Definisi Operasional Variabel dalam Penelitian ini adalah:

a. Efektivitas Diri. Efektivitas diri adalah keyakinan pribadi dari sebuah persepsi individual akan kemampuan mereka untuk melakukan sebuah tindakan yang diperlukan untuk mencapai sebuah hasil (Bandura, 1997). Pengukuran konstruk efektivitas diri diadopsi dari Dinev (2002) dengan memberikan 28 butir pertanyaan kepada responden yang terdiri dari 2 faktor. Faktor efektivitas diri terdiri dari 2 dimensi yaitu:

1) Efektivitas diri yang berhubungan dengan pemakaian internet secara umum (general internet self-efficacy). Efektivitas diri untuk pemakaian internet secara umum berhubungan dengan kepercayaan individual akan kemampuan mereka melakukan kegiatan internet secara umum tanpa bantuan orang lain, seperti menjelajahi internet, membaca berita secara online, mengkustomasi sebuah situs, membeli barang secara online, dan menggunakan $e$-mail.

2) Efektivitas diri yang berhubungan dengan pemakaian aplikasi internet tingkat lanjutan (advanced internet self-efficacy). Efektivitas diri untuk pemakaian aplikasi 
internet tingkat lanjutan berhubungan dengan kepercayaan individual untuk melakukan lebih banyak kegiatan internet tingkat lanjutan, yang mana biasanya memerlukan aplikasi lainnya selain sebuah browser. Kegiatan-kegiatannya mencakup file sharing, membuat situs web, menggunakan ftp, discussion board, dan chat room.

b. Faktor Spesifik Internet. Faktor spesifik internet adalah faktor-faktor yang mempengaruhi seseorang ketika hendak ataupun telah menggunakan internet (Dinev, 2002). Pengukuran konstruk faktor spesifik internet diadopsi dari Dinev (2002) dengan memberikan 11 butir pertanyaan kepada responden yang terdiri dari 3 faktor. Dimensi dari 3 faktor spesifik internet terdiri dari:

1) Faktor keamanan (security concern), adalah faktor yang meliputi penyalahgunaan informasi pribadi, informasi keuangan dan privacy.

2) Faktor intrusi (intrusion concern), adalah faktor yang meliputi kepedulian pemakai internet terhadap perilaku yang bersifat mengganggu, perasaan diawasi, rasa takut komputer terinfeksi virus ataupun di-hack.

3) Faktor teknis (technical concern), adalah faktor berhubungan dengan tantangan dari pemakai internet untuk mengatasi kesulitan teknis dalam melakukan koneksi ke internet.

c. Ansietas Pengguna Internet. Ansietas pengguna internet adalah kegelisahan pikiran pengguna akan terjadinya sesuatu yang berbahaya saat menggunakan internet (Dinev, 2002). Pengukuran konstruk ansietas pengguna internet diadopsi dari Dinev (2002) dengan memberikan 25 butir pertanyaan kepada responden yang terdiri dari 3 faktor. Faktor ansietas pengguna internet terdiri dari 3 dimensi, yaitu:

1) Ansietas kerusakan internet (internet damage anxiety), adalah ketakutan akan pemakaian internet dapat menyebabkan kerusakan pada komputer, lingkungan atau pada suatu proses.

2) Ansietas tugas internet (internet task anxiety), adalah ketakutan dalam melakukan tugas pada internet.

3) Ansietas sosial internet (internet social anxiety), adalah ketakutan akan perasaan malu ketika menggunakan internet.

Populasi dalam penelitian ini adalah seluruh dosen, tenaga kependidikan, dan mahasiswa yang aktif pada tahun akademik 2016/2017 di Universitas Universal (UVERS). Responden dipilih dengan metode purposif dikarenakan obyek yang tidak besar. Data yang digunakan dalam penelitian ini adalah data primer yang didapat dari jawaban responden yang tecatat dalam kuisioner yang berisi sejumlah pertanyaan dan jawaban dengan menggunkan 5 (lima) poin skala Likert yang dimulai dari sangat setuju (1) sampai dengan sangat tidak setuju (5). Maka berdasarkan perhitungan untuk puprposive sampling, sebanyak 315 buah kuisionaer dibagikan dengan rincian: 256 orang mahasiswa aktif dan 56 orang dosen dan tenaga kependidikan.Dari jumlah tersebut, sebanyak 245 kuesioner kembali dan dari hasil uji outlier menunjukkan 23 kuesioner tidak dapat disertakan sehingga hanya 222 kuesioner yang digunakan dalam pengujian selanjutnya.

Selanjutnya, dari data yang masuk, dilakukan berbagai pengujian, antara lain:

1. Uji Outlier dan Normalitas Data. Uji outlier dilakukan untuk menguji data bila terdapat yang menyimpang dari rata-ratanya. Data yang memiliki nilai z lebih kecil dari nilai kritis -2,56 atau lebih besar dari nilai kritis 2,56 merupakan data yang menyimpang dari rata-rata. Untuk data yang menyimpang dari rata-ratanya akan dikeluarkan dari analisis data selanjutnya. Uji normalitas data dilakukan untuk 
menentukan apakah data terdistribusi dengan normal. Metode yang digunakan untuk uji normalitas adalah analisis grafik normalitas dengan menggunakan pendekatan normal probability plot. Persyaratan normalitas terpenuhi jika data menyebar di sekitar garis distribusi normal berbentuk diagonal lurus (Hair et al., 2010).

2. Uji Multikolinearitas. Uji multikolinieritas dilakukan untuk memastikan tidak ada korelasi antara variabel independen. Pengujian multikolinieritas menggunakan Variance Inflation Factor (VIF). Apabila nilai VIF lebih besar dari 10 (Hair et al., 2010), maka variabel tersebut mempunyai persoalan multikolinieritas dengan variabel independen yang lainnya.

3. Uji Hipotesis. Pengujian hipotesis menggunakan regresi berganda, ini dikarenakan variabel independen dalam penelitian ini terdiri dari 2 variabel. Model regresi berganda digunakan untuk menganalisis hubungan antara variabel independen yaitu Efektivitas diri dan Faktor spesifik internet dengan variabel dependen yaitu Ansietas pengguna internet.

\section{HASIL PENELITIAN DAN PEMBAHASAN}

\section{Karakteristik Variabel}

Statistik deskriptif (total sampel, minimum, maksimum, rata-rata dan deviasi standar) dari semua variabel yang digunakan dalam penelitian ini adalah:

Tabel 1: Karakteristik Variabel

\begin{tabular}{llllll}
\hline Variabel & $\mathbf{N}$ & Minimum & Maksimum & Rata-rata & $\begin{array}{l}\text { Deviasi } \\
\text { Standar }\end{array}$ \\
\hline Efektivitas diri & 222 & 1,23 & 1,77 & 1,4891 & 0,10520 \\
\hline $\begin{array}{l}\text { Ansietas pengguna } \\
\text { internet }\end{array}$ & 222 & 1,10 & 1,70 & 1,3918 & 0,12468 \\
\hline Faktor spesifik internet & 222 & 1,19 & 1,79 & 1,4742 & 0,11004 \\
\hline
\end{tabular}

Sumber: Hasil olahan SPSS (2018)

Tabel 1 (satu) di atas menunjukkan rata-rata dari variabel berkisar antara 1,3918 sampai dengan 1,4891. Variabel efektivitas diri memiliki rata-rata 1,4891 dengan deviasi standar sebesar 0,10520. Sedangkan variabel faktor spesifik internet memiliki rata-rata sebesar 1,4742 dengan deviasi standar sebesar 0,11004. Nilai deviasi standar menunjukkan bahwa pengaruh faktor spesifik internet terhadap ansietas pengguna internet sedikit lebih bervariasi dibandingkan efektivitas diri. Untuk variabel ansietas pengguna internet, nilai rata-ratanya adalah sebesar 1,3918 dan deviasi standar sebesar 0,12468 .

\section{Normalitas dan Data Outlier}

Uji normalitas data dilakukan untuk menentukan apakah data terdistribusi dengan normal. Uji normalitas menggunakan tes Kolmogorov-Smirnov dan tes Shapiro-Wilk. Hasilnya menunjukkan bahwa data variabel Efektivitas diri memiliki nilai signifikansi $<0,05$ yang menunjukkan bahwa data tidak menyebar normal. Namun apabila dilihat dari gambar plot Q-Q, data variabel Efektivitas diri adalah normal. Data untuk variabel Faktor spesifik internet dan Ansietas pengguna internet memiliki nilai signifikansi > 0,05 yang menunjukkan bahwa data menyebar normal. 
Tabel 2: Hasil Uji Normalitas

\begin{tabular}{lllllll}
\hline & \multicolumn{2}{l}{ Kolmogorov-Smirnov } & \multicolumn{3}{l}{ Shapiro-Wilk } & Sig. \\
\hline & Statistic & Df & Sig. & Statistic & df & \\
\hline Efektivitas diri & 0,076 & 222 & 0,004 & 0,979 & 222 & 0,002 \\
\hline Faktor spesifik internet & 0,093 & 222 & 0,000 & 0,984 & 222 & 0,012 \\
\hline Ansietas pengguna internet & 0,090 & 222 & 0,000 & 0,985 & 222 & 0,016 \\
\hline
\end{tabular}

Normal Q-Q Plot of TransR_ISE

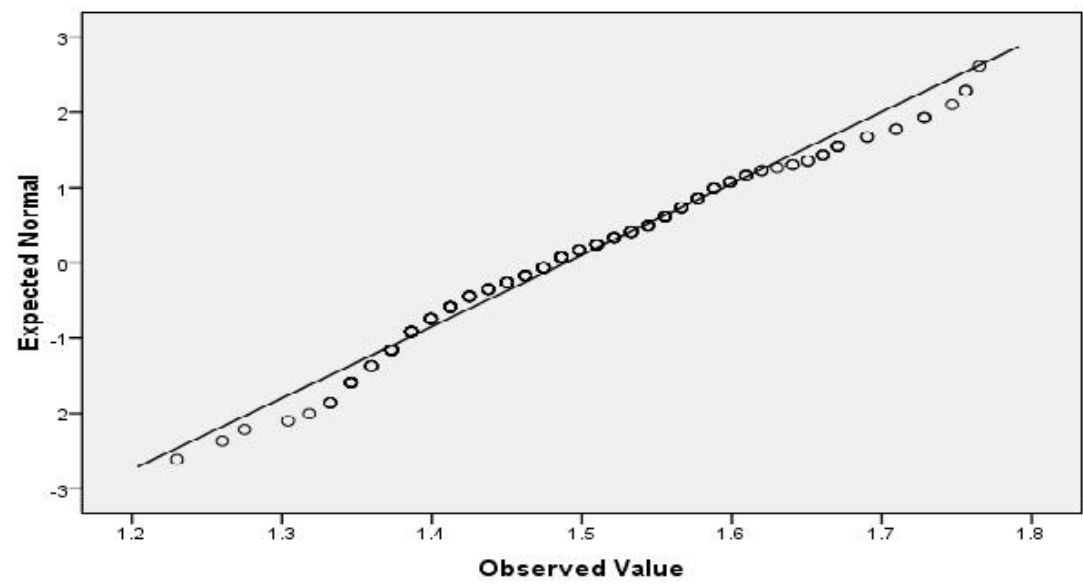

Sumber: Hasil olahan SPSS

\section{Gambar 2: Hasil Uji Q-Q Plot Variabel Efektifitas diri}

\section{Multikolineritas}

Pengujian multikolinieritas dilakukan untuk memastikan tidak ada korelasi antar variabel independen yang menyebabkan pengaruh suatu faktor menjadi lemah. Uji multikolinieritas menggunakan Variance Inflation Factor (VIF).

Tabel 3: Hasil Uji Multikolinieritas

\begin{tabular}{lllll}
\hline \multirow{2}{*}{ Model } & \multicolumn{2}{l}{ Collinearity Statistics } & \multicolumn{2}{l}{ Kesimpulan } \\
\cline { 2 - 3 } & Tolerance & VIF & & Tidak \\
Efektivitas diri & 0,825 & 1,211 & $\begin{array}{l}\text { memiliki } \\
\text { multikolinieritas }\end{array}$ & hubungan \\
\hline Faktor spesifik internet & 0,825 & 1,211 & $\begin{array}{l}\text { Tidak } \\
\text { multikolinieritas }\end{array}$ & hubungan \\
\hline
\end{tabular}

\section{Sumber: Hasil olahan SPSS}

Hasil pengujian multikolinieritas menunjukkan nilai VIF kurang dari 10 (Hair et al., 2010). Hal ini berarti tidak terjadi persoalan multikolinieritas antara sesama variabel independen yaitu efektivitas diri dan faktor spesifik internet.

\section{Analisis Hasil Uji Hipotesis}

Pengujian hipotesis menggunakan regresi berganda, ini dikarenakan variabel independen dalam penelitian ini terdiri dari 2 variabel. Model regresi berganda digunakan untuk menganalisis hubungan antara variabel independen yaitu Efektivitas diri dan Faktor spesifik internet dengan variabel dependen yaitu Ansietas pengguna 
internet. Hasil pengujian regresi berganda antara Efektivitas diri dan Faktor spesifik internet terhadap Ansietas pengguna internet disajikan pada tabel berikut ini.

Tabel 4: Hasil Uji F (ANOVA ${ }^{\text {b }}$ ) dari Model Regresi Berganda

\begin{tabular}{|c|c|c|c|c|c|c|}
\hline & Model & $\begin{array}{l}\text { Sum } \\
\text { Squares }\end{array}$ & $\begin{array}{ll}o f & \\
& \text { Df }\end{array}$ & $\begin{array}{l}\text { Mean } \\
\text { Square }\end{array}$ & $\mathbf{F}$ & Sig. \\
\hline 1 & Regression & 0,211 & 2 & 0,106 & 7,182 & $0,001^{\mathrm{a}}$ \\
\hline & Residual & 3,224 & 219 & 0,15 & & \\
\hline & Total & 42,811 & 221 & & & \\
\hline
\end{tabular}

a. Predictors: Faktor spesifik internet, Efektivitas diri

b. Dependent Variable: Ansietas pengguna internet

Sumber: Hasil olahan SPSS

Hasil uji ANOVA atau uji F menunjukkan tingkat signifikansi sebesar 0,001 (p $<0,01)$. Hal ini berarti model regresi dapat digunakan untuk memprediksi ansietas pengguna internet. Hasil pengujian regresi efektivitas diri dan faktor spesifik internet terhadap ansietas pengguna internet disajikan pada Tabel di bawah.

Tabel 5: Hasil Uji Regresi Linier Berganda

\begin{tabular}{lllllll}
\hline Model & & \multicolumn{2}{l}{$\begin{array}{l}\text { Unstandardized } \\
\text { Coefficients }\end{array}$} & $\begin{array}{l}\text { Standardized } \\
\text { Coefficients }\end{array}$ & t & Sig. \\
\hline & B & Std. Error & Beta & & \\
\hline 1 & Konstanta & 0,895 & 0,134 & & 6,682 & 0,000 \\
\hline & Efektivitas diri & 0,131 & 0,085 & 0,111 & 1,540 & 0,125 \\
\hline $\begin{array}{l}\text { Faktor } \\
\text { internet }\end{array}$ & spesifik & 0,204 & 0,082 & 0,180 & 2,503 & 0,013 \\
\hline
\end{tabular}

Dependent Variable: Ansietas pengguna internet Sumber: Hasil olahan SPSS

Hasil pengujian menunjukkan bahwa variabel efektivitas diri memiliki nilai signifikansi sebesar 0,125 . Hal ini berarti efektivitas diri memiliki pengaruh yang tidak signifikan terhadap tingkat ansietas pengguna internet, karena tingkat signifkansi lebih besar dari 10\% ( $\mathrm{p}<0,1)$. Hasil ini tidak konsisten dengan penelitian Dinev (2002) yang menyatakan bahwa efektivitas diri memengaruhi ansietas pengguna internet.

Variabel faktor spesifik internet memiliki nilai signifikansi sebesar 0,013 . Hal ini berarti terdapat hubungan yang signifikan antara faktor spesifik internet dengan tingkat ansietas pengguna internet. Hasil penelitian menunjukkan nilai signifikan sebesar 0,013, jauh lebih kecil dari tingkat signifikan yang bisa diterima yaitu $10 \%$ ( $\mathrm{p}<$ 0,1). Hasil ini konsisten dengan penelitian Dinev (2002) yang menyatakan bahwa faktor spesifik internet mempengaruhi tingkat ansietas pengguna internet.

Tabel 6:Hasil Perhitungan Koefisiensi Determinasi dari Model Regresi Berganda

\begin{tabular}{llll} 
Model & $\mathbf{R}$ & $\mathbf{R}^{\mathbf{2}}$ & Adjusted $\mathbf{R}^{\mathbf{2}}$ \\
\hline 1 & $0,248^{\mathrm{a}}$ & 0,062 & 0,053
\end{tabular}

a. Predictors: konstanta, Faktor spesifik internet, Efektivitas diri Sumber: Hasil olahan SPSS 
Hasil pengujian koefisiensi determinasi menunjukkan koefisiensi determinasi $\left(\mathrm{R}^{2}\right)$ memiliki nilai sebesar 0,062 yang berarti ansietas pengguna internet dapat dijelaskan oleh variabel efektivitas diri dan faktor spesifik internet sebesar $6,2 \%$. Sedangkan sisanya sebesar $93,8 \%$ dipengaruhi oleh faktor-faktor yang lain. Hal ini menjelaskan bahwa model penelitian yang digunakan untuk mengetahui tingkat Ansietas pengguna internet belum lengkap. Masih banyak faktor lain yang belum diteliti, sehingga memerlukan waktu tambahan untuk dapat mendapatkan tingkat signifikansi yang lebih baik.

\section{E. PENUTUP}

Dari hasil penelitian dan pembahasan diatas, dapat disimpulkan bahwa Efektivitas diri tidak memiliki pengaruh yang signifikan dengan Ansietas pengguna internet. Hal ini juga menunjukkan semakin tinggi tingkat efektivitas diri seorang pemakai internet, maka belum tentu menyebabkan perubahan tingkat Ansietas pengguna internet. Hal ini tidak konsisten dengan penelitian Dinev (2002) yang menyatakan bahwa ada hubungan yang signifikan antara Efektivitas diri dengan Ansietas pengguna internet. Untuk faktor spesifik internet, memiliki pengaruh yang signifikan dengan Ansietas pengguna internet. Hasil ini konsisten dengan penelitian Dinev (2002). Berdasarkan uji koefisien determinasi, model yang dipilih untuk penelitian ini belum lengkap karena hanya dapat memprediksikan tingkat Ansietas pengguna internet sebanyak $6,2 \%$. Hal ini bisa dinyatakan bahwa untuk menilai tingkat Ansietas seorang pengguna internet dibutuhkan faktor lain, seperti: Pengaruh atasan, persepsi tentang kegunaan layanan, dan lainnya seperti yang sirat pada penelitian Konerding (2000).

Dari hasil penelitian ini juga tampak bahwa dalam hal menggunakan internet, pengguna hanyalah dipengaruhi oleh Faktor spesifik internet. Terdapat faktor-faktor lainnya antara lain, seperti: kemudahan menggunakan, perintah atasan, kerja kelompok, dan waktu penggunaannya. Hal ini berarti agar dapat meningkatkan penggunaan internet untuk menyelesaikan tugas-tugas pekerjaan, Universitas Universal haruslah dapat melakukan pembinaan penguasaan teknologi secara personal. Sehingga seluruh sivitas akademika akan mampu bekerja mandiri dan lebih cepat dengan menggunakan teknologi internet dan layanan yang terkait.

Bagi peneliti selanjutnya yang ingin mengembangkan penelitian ini, hendaknya menggunakan teknik wawancara dalam metode pengumpulan data sehingga responden benar-benar mengisi kuesioner sesuai dengan kenyataan (terlihat) serta menambahkan variable-variabel lain. Peneliti juga bisa memberi penjelasan kepada responden jika ada pertanyaan/pernyataan pada kuesioner yang kurang dimengerti.. Karena dalam penelitian ini menggunakan instrumen yang disebarkan melalui perantara. Ini memungkinkan responden berada dalam kondisi yang tidak ideal pada saat menjawab.

\section{DAFTAR PUSTAKA}

Al-Jabri, I., dan Al-Khaldi, M. (1996). Effects of user characteristics on computer attitudes among undergraduate business students. Journal of End User Computing. 9, p. 16-22.

Ayersman, D. J. dan Reed, W. M. (1995). Effects of learning styles, programming, and gender on computer anxiety. Journal of Research on Computing in Education, 28 (2), p. 148-161. 
Bandura, A. (1997). Self-efficacy: The exercise of control. Personal Psychology [pps], vol. 50 Iss. 3 Autumn 1997, p. 801-804.

Bashir, I \& Madhavaiah, C. (2015). Trust, Social Influence, Self-Efficacy, Perceived Risk and Internet Banking Acceptance: An Extension of Technology Acceptance Model in India Context. www.methamorphosisjournal.com, vol. $14(1)$

Bower Jr., D. A. dan Bowers, V. M. (1996). Assessing and coping with computer anxiety In the social science classroom. Social Science Review. 14(4), p. 439443.

Boyle, R. dan Ruppel, C. (2003). On-line purchasing intent: the effect of personal innovativeness, perceived risk, and computer self-efficacy. Proceedings of the 7th Annual Conference of the Southern Association for Information Systems, p. $131-137$.

Decker, C. A. (1998). Training transfer: perceptions of computer use self-efficacy among university employees. Journal of Vocational and Technical Education, Spring Vol. 14 No. 2.

Dinev, T. (2002). Self-Efficacy and Internet Usage - Measurement and Factorial Validity. http://www.fau.edul-tdinev/publications/anx.pdf.

Dinev, T. dan Koufteros, X. (2003). Internet Self-Efficacy and Internet Usage- Testing A Measurement and A Structural Model. http://www.fau.edultdinev/publications/int.pdf.

Eastin, M. S. dan LaRose, R. (2000). Internet self-efficacy and the psychology of the digital divide. .JCMC 6 (1) September.

Feldman, R. A. (2000). On the relation of computer anxiety and information literacy. $21^{\text {st }}$ STAR Conference, Bratisiava, Slovakia July 20-22, 2000.

Glass, C. R. dan Knight, L. A. (1988). Cognitive factors in computer anxiety. Cognitive Therapy and Research, 12 (4), p. 35 1-366.

Hair, J. F., Black, W. C., Babin, B. J., dan Anderson, R. E. (2010). Multivariate Data Analysis, Pearson, $7^{\text {th }}$ edition, United States.

Hapson, S. A. (2001). Assessing and coping with technology anxiety. Spring 2001.

Harris, I. (2017). Analisis Technology Acceptance Model (TAM) Terhadap Tingkat Penerimaan E-learning Pada Kalangan Mahasiswa (Studi Empiris Pada Universitas Internasional Batam dan UPBJJ-UT Batam). Jurnal Terapan Manajemen dan Bisnis, 3(1).

Huang, S. L., Waxman, H. C., dan Padron, Y.N. (1995). Teacher Education students' attitudes toward educational computing. In D. A. Willis, B. Robin, and J.W. Willis (Eds.), Technology and Teacher Education Annual 1995. Charlottesville, VA: Association for the Advancement of Computing in Education, p. 769-773.

Johnson, D. M., Lester, M. L., dan Ferguson, J. A. (2001). Analysis of the relationships between computer experiences, self-efficacy, and knowledge of undergraduate students entering a land-grant college of agriculture. $28^{\text {th }}$ Annual National Agricultural Education Research conference, December 12, p.1-13.

Konerding, U. (2000). The effects of two computer-related university courses on computer anxiety and computer self-efficacy. Institute for Education and Computer Science. 
Lopez, D. A. dan Manson, D. P. (1997). A study of individual computer self-efficacy and perceived usefulness of the empowered desktop information system. Business Administration Computer Information System. Fall, p. 83-92.

McInemey, V., Mclnerney, D.M., dan Sinclair, K. (1994). Student teachers, computer anxiety and computer experience. Journal of Educational Computing Research, 11(1), p. 27-50.

O'Neil, L. (1995). On technology and schools: a conversation with Chris Dede. Educational Leadership, v.53(2), 6-12.

Presno, C. (1998). Taking the byte out of the internet anxiety: instructional techniques that reduce computer/internet anxiety in the classroom. Journal of Educational Computing Research, Vol. 18(2) 1998, p. 147-161. 